\title{
OF MEAT, MEN AND PROPERTY: THE TROUBLED CAREER OF A CONVERT NUN IN EIGHTEENTH-CENTURY KIEV
}

\author{
Dr Liudmyla Sharipova \\ Department of History \\ School of Humanities \\ University Park \\ University of Nottingham \\ Nottingham NG7 2RD \\ United Kingdom \\ Email: liudmyla.sharipova@nottingham.ac.uk
}

Manuscript length: 10,715 words (with notes)

\begin{abstract}
The article is based on the case study of Sister Asklipiodata, a Jewish convert to Christianity, who became a member of the monastic community in one of Kiev's Orthodox convents in the second half of the eighteenth century. It explores the ways in which the non-communal way of life in Eastern Orthodox convents impacted both upon the praxis of monastic existence within the convent walls, and the relations with the secular world without. Parallel to this consideration of a lasting centrality of property ownership in Orthodox female monasticism, the article addresses the largely neglected question of Jewish assimilation in the Russian Empire prior to the Partitions of Poland (1772-93), which brought the sizeable Jewish population of the Commonwealth's eastern borderlands in immediate contact with the Russian state.
\end{abstract}




\section{OF MEAT, MEN AND PROPERTY: THE TROUBLED CAREER OF A CONVERT NUN IN EIGHTEENTH-CENTURY KIEV}

Against the veritable explosion of research in Catholic women's communities over the last several decades, female monasticism in the Eastern Orthodox Church still remains a relatively understudied subject. ${ }^{1}$ The present essay aims to redress this imbalance by considering the case study of Sister Asklipiodata, a Jewish convert to Christianity who took the veil in an Orthodox convent in the Ukrainian Hetmanate in the second half of the eighteenth century. A semi-autonomous state that included territories to the east of the Dnieper River with the city of Kiev on its right, western, bank, the Hetmanate was ruled by elective hetmans who recognised the tsar of Muscovy as their suzerain. The 1654 Pereiaslav Treaty that created the Hetmanate recognised Russian protectorate over the Ukrainian lands in return for the tsar's guarantee of the traditional rights and privileges their Orthodox population exercised under the Polish-Lithuanian rule, including local ecclesiastical practices, property rights of religious institutions, and individual freedoms

of monastic and clerical personnel. ${ }^{2}$ Despite the abolition of Ukrainian political autonomy in 1764 , individuals in holy orders continued to enjoy a special legal status secured under the Treaty until the secularisation of ecclesiastical properties in 1786 signalled a major weather change in monastic organisation in the Hetmanate's former territories. Ukrainian monasteries' non-communal and relatively lax regime under the benevolent rule of local clerical hierarchy gave way to a communal way of life, effectively controlled by the imperial state through the offices of the Holy Synod based in St Petersburg. ${ }^{3}$ 
In the rest of the Russian Empire the archaic non-communal (ideorrhythmic) monastic regime had been replaced with communal living after the secularisation of monasteries in 1764 . The latter refers 'not only to a common table and church services in common, but also to a common distribution both of work and of all necessary provisions'. The monastic individual, whether working with others or alone, gave his or her work over to his or her superior; s/he received no individual pay or goods, but only what s/he needed from the common stores. ${ }^{4}$ Under the ideorrhythmic way of monastic organisation, not being able to support herself financially was a significant obstacle for a woman who wished to retire to a convent. Once admitted to the community, many novices purchased their own 'cells' (these were stand-alone or semi-detached structures that could range between a primitive hut and a palatial house) in monastery grounds, which could subsequently be sold on or even inherited by next of kin. ${ }^{5}$ Nuns traded their own handiwork, continued to oversee private financial interests outside monastery walls, and each had a share in certain types of the monastery's produce, especially alcohol. To a great extent personal property conferred status and became the engine of social interaction both within and without convent grounds. 'Property ... involves rights, privileges, powers, and immunities that govern the relative power of individuals over tangible and intangible things. ${ }^{9}$ Property relationships thus naturally morphed into social relations.

While benefitting individuals whose financial standing was secure enough to afford them confortable living within monastery walls, ideorrhythmic practices often proved deleterious to monastic discipline. Sophia Senyk describes the absence of common life as 'one of the ills of eastern monasticism, in all countries and at all 
periods'. ${ }^{7}$ Possession of money, goods and chattels by monks and nuns contradicted the most basic principles of monastic life such as the rule of poverty and obedience to superiors, complicated hierarchical relationships, created the sense of inequality among the inmates, and distracted them from the daily regimen of prayer and contemplation. ${ }^{8}$ The only two areas that remained common to the inmates within the ideorrythmicallyorganised monastic community, were liturgic services and the cemetery. ${ }^{9}$ Prior to the secularisations of the late eighteenth century, no expectation existed of Orthodox nuns engaging in charitable activities such as work in hospitals or orphanages. As often as not, property-centred conflicts became internal disputes about authority, as well as personal and communal rights. Most importantly, property relationships kept the sisters wedded to the world of secular concerns they were supposed to shun. The case study examined below amply demonstrates that the idea of property even extended to a woman's right to regulate interference with her body in a variety of contexts - familial, professional and legal.

The problems and contradictions that blighted Sister Asklipiodata's life as a nun were not unique to her and were to a great extent the consequence of the fact that pre1786 monastic existence in the Ukrainian Hetmanate was based on archaic, poorly articularted principles. A revision of these principles was required in order to repair the cleavage between commonly shared traditional perceptions of monasticism as the highest expression of Christian life and the often mundane experience of convent living; to effect a paradigm shift in the social function of women's monasteries; and to address the persistence both within and without the convent walls of property-based relationships that frequently clashed with spiritual values. Asklipiodata's Jewish origins and her 
conversionary experience that occurred just a few decades prior to the Partititons of Poland (1772-93) and the institution of the Pale of Settlement, however, are comparatively unique. ${ }^{10}$ As such they offer a rare glimpse of the largely neglected question of Jewish-Christian relations in the Empire before the Partitions brought the sizeable Jewish population of the Polish-Lithuanian Commonwealth's eastern borderlands in immediate contact with the Russian state. ${ }^{11}$ In addition, the cultural and religious values of Asklipiodata's younger years must have had a bearing on the way in which she later related to her life in an Orthodox monastery.

Born c. 1715 to the ancient Jewish community of Prague, known at the time as 'a mothercity in Israel', Sister Asklipiodata's provenance was fairly exotic by the standards of eighteenth-century Kiev. ${ }^{12}$ Her late husband had been a burgess in Kiev and 'Jewish' (meshchanin ... Ivreianin). ${ }^{13}$ Her family had probably been forced to leave Prague in 1745, the year that saw the expulsion of Jews from the city. ${ }^{14}$ The description of her husband as 'Jewish', however, may be misleading. An interconfessional marriage between a man who was Jewish by religion and a Christian Orthodox woman was impossible. Like anywhere else in Europe at the time, 'conversion was necessary because civil marriage did not exist' ${ }^{15}$ Jewish survival in the Russian Empire came at a price, as following the publication of Empress Elizabeth I's 1742 Manifesto proscribing Jewish habitation in the imperial territories, legitimate settlement in the Empire, particularly the Ukrainian borderlands east of the Dnieper River, was only allowed to the Jews willing to convert to the Orthodox religion. Those refusing to apostatise were ordered to leave, their liquid assets in gold and silver coinage confiscated at the border and exchanged for low- 
value copper money or paper promissory notes $\left(\right.$ veksel' $\left.^{\prime}\right) .{ }^{16}$ No statistics throwing light on pre-1791 Jewish residency in Kiev are available, since the settlement of unconverted Jews in the Russian Empire was illegal, Jewish converts to Christianity were no longer officially classified as Jews by religion, and ethnic qualifications at law did not exist. Thus a legitimate status as a Kievan burgess and householder enjoyed by her husband implies an earlier conversion from Judaism to Christianity. Moreover, as will be discussed below, the conversion involved an extended family, not just Asklipiodata and her husband. The use of the descriptor 'Jewish' with regard to her husband thus supplies a useful reminder that, despite the legal principle that any Jew who had formally converted to Christianity ceased to be Jewish in the eyes of the imperial law, from the point of view of the society that accepted them, the memory of the convert's former identity could not be shed instantly.

If the future Sister Asklipiodata had left Prague in the 'disaster year' of 1745, when she was around thirty years of age, she would have already been married by then. It therefore seems probable that decisions regarding her movements on leaving Bohemia rested with her husband. Going eastward toward Poland-Lithuania was sensible, for during times of peace the Commonwealth offered a degree of tolerance and chances to earn a livelihood to the many Ashkenazi Jews who inhabited its provinces. ${ }^{17}$ Poland's eastern borderlands encompassing the troubled Right-Bank Ukraine, however, both opened up advantageous employment and trade opportunities for Jews, and were increasingly a dangerous place due to the growth of the popular haidamak movement. ${ }^{18}$ The haidamak rebellion of 1750 could have driven Bohemian Jewish refugees farther east, into the relative safety and security of the Russian-controlled Left-Bank Ukraine. 
Medieval canon law stipulated that 'Jews be wooed to the church not by physical compulsion but with softer forms of persuasion (blandimentis), including an enforced level of marked social and legal inferiority'. ${ }^{19}$ In Central Europe, with its long tradition of Jewish settlement, the hardening of religious lines came to replace the lively, if rarely balanced, Jewish-Christian debates of the first decades after Luther's Reformation. What followed in the seventeenth and eighteenth centuries was a complex pattern of conversions, in which sincere conviction could not always be easily distinguished from the compulsion to apostatise determined by external factors. Motives behind Jewish conversions thus became increasingly mixed, but for most of the eighteenth century it was the less socially and economically protected who sought refuge from persecution and discrimination through the drastic option of changing their religion. ${ }^{20}$ The available archival records of female Jewish conversions in the Metropolitanate of Kiev back up this hypothesis. For all of them, without exception, conversion became a choice after losing their family or guardians, being repudiated by a Jewish husband, or running away from home. ${ }^{21}$ Whether unmarried, divorced or widowed, left on her own, a Jewish woman with no independent income and no place to go had to rely on the kindness of strangers, either Jewish or gentile. ${ }^{22}$ On the other end of the spectrum, an Orthodox identity assumed on conversion, especially when it was combined with the ownership of property, provided women with a degree of independence and a range of choices.

It is impossible to trace either Sister Asklipiodata's original Jewish name, or the secular Christian name she adopted on conversion. The 1771 list of monastic personnel on which her full monastic name appears as 'Asklipiodata Grigorieva Kashporovna', however, offers a glimpse of the names of her husband: 'Grigorii' (with its Greek roots, 
this was almost certainly the name he received on conversion to Orthodoxy), and father: 'Kashpor' or 'Kasper' (it sounds Central European and has Hebrew origins). ${ }^{23}$

Asklipiodata's husband must have been dead by 1766, the year when she is known to have entered the St Nicholas Holy Jordan Monastery and started her novitiate, made possible by her status as a widow. Her ownership of a house in the nearby Podil district was likewise a useful qualification, as, due to Orthodox monasteries' persistent attachment to the non-communal regime, very poor women found attaining monastic profession impossible. ${ }^{24}$ That she was not destitute makes it improbable that the prospect of homelessness and starvation drove her to the convent. The motivation behind this lifechanging decision is likely to have been a combination of factors, including the evident absence of living children, loneliness in an adoptive country, Asklipiodata's deep, if possibly mixed, religiosity, and considerations of prestige and status associated with the high regard traditionally accorded to monks and nuns in Orthodox society. The Church and popular religion regarded people who adopted 'angelic status' (angel'skii chin), i.e. took monastic vows, as exceptional individuals who entered a monastery in search of salvation, as well as praying for the souls of those in the outside world.

Unlike Asklipiodata's ancestral religion, Christianity held out to its followers a systematically developed promise of an afterlife beyond the grave. ${ }^{25}$ If she had had no ambition beyond living out her days in peace, but feared the emptiness of a solitary existence in her own home, she could arguably have moved in with relatives or settled near them. Instead, to cite the famous New Testament phrase, she chose the very 'small gate' and 'narrow road' (Matthew, 7:14) of monasticism to earn salvation. To what extent she appreciated the finer theological points of Christianity, or whether she ever came to 
think of Judaism as inherently wrong, is impossible to tell. Anyway, '[d]octrinal theology rarely offers a solution in ... emotional crises', and when she found herself at a crossroads of life, the future Sister Asklipiodata faced a range of options from which to choose her future. ${ }^{26}$

Similar to other 'religions of the book', the devotional cycle of Judaism is regulated by clock and calendar (morning, afternoon and evening prayers, weekday, Sabbath, and festival prayers). The existence of tkhines, distinctive voluntary prayers in Yiddish, written for women and occasionally even by women, not only points out that Judaism had a specific place allocated to female devotion (even if it was reserved for the domestic and private spheres), but also that deliberate attempts were undertaken to make the purpose of this devotion intelligible to women. Notably, after the first collection of tkhines appeared in print in Asklipiodata's native Prague in 1590, the city remained one of the main centres of their publication between 1648 and the first decades of the eighteenth century. ${ }^{27}$

Although the idea of celibacy, in the sense of sexual abstinence for religious reasons, was known in Judaism, it was reserved for men, as women were not considered to be sufficiently evolved spiritually to benefit from it, and were actively discouraged from practicing a celibate lifestyle. At the same time, Jewish women who had spiritual pretensions sometimes deliberately played with it either by specifically abstaining from sex or otherwise secluding themselves from the bustle of everyday life. ${ }^{28}$ In the early nineteenth century, while spending time in solitude at her mother's grave - a distinctly female activity in Judaism - Hannah Rachel Werbermacher, the famous Maiden of Ludmir, was wondering about her 'right to possess all of the [spiritual] levels that men 
possess' ${ }^{29}$ The future nun Asklipiodata, a Jewish convert entering an Orthodox monastery, may have felt that by doing so she was raising herself above the station traditionally ascribed to women in her ancestral faith. As such her monastic career represents an interesting case of Judaeo-Christian religious syncretism.

The prestige of monastic profession permeating Orthodox society, which in Asklipiodata's case was very likely associated with an aspiration to a higher social status, without a doubt provided an additional strong incentive. The future Sister Asklipiodata's extraordinarily ambitious choice of monastic career in the Orthodox Church also could have been a reflection of an irrepressible sense of self-worth on her part. According to Gershon David Hundert, 'Self-affirmation and a feeling of Jewish superiority ... dominated the spectrum of self-evaluation of eastern European Jews ... despite their contradictory and manifold adaptations and acculturations ${ }^{30}$ Ownership of property both provided her with financial security and was a safeguard that her motives for taking the veil could be spiritual and idealistic, as even her apparent desire of social advancement entailed hardly any pragmatic benefits beyond the acquisition of the sought-after 'angelic status'.

The two years following Asklipiodata's entry to the monastery witnessed her meteoric rise to becoming a fully professed nun in $1769 .{ }^{31}$ The available statistical data about admission to the novitiate and profession in Ukrainian female monasteries in the 1760s help to contextualise this advanced career progression under the fluctuating conditions of state-regulated access to monastic status. In accordance with basic canonical rules reinforced by the Petrine 1722 Addendum to the Spiritual Regulations (Dukhovnyi 
reglament), specifically aimed at monastic individuals, the minimum period of novitiate was set at three years, although in the first half of the eighteenth century few aspirants managed to attain monastic status as quickly as that. The average wait between entering monastery and profession constituted seven to ten years, but some women had to possess their soul in patience for fifteen or even twenty years. ${ }^{32}$ It was easier for a woman in her fifties to achieve profession than for a younger candidate, whose age fell short of the constantly moving goal posts of between forty and sixty years of age, which the imperial legislation stipulated as suitable for monastic admission. ${ }^{33}$ The year of Asklipiodata's entry to the convent, 1766 , saw a small rise in admissions after a temporary lull that followed the secularisation of monasteries in Great Russia in 1764, which did not apply to the Ukrainian territories but nonetheless visibly affected the Kiev church authorities' confidence in drawing new monastic recruits. ${ }^{34}$

1769 , the year of Asklipiodata's profession, was a veritable annus mirabilis for the Holy Jordan community of nuns: as many as eighteen sisters achieved monastic status that year..$^{35}$ That, unlike Asklipiodata, some of them had to wait between six and sixteen years for that day, underscores the speed of her progression to a full profession. Above all, it serves as a testimony to her urgent desire to become a nun: in the eighteenth century candidates who wished to take the veil had to appeal to the consistory authorities for permission to do so. ${ }^{36}$ Since instant success was extremely rare, and unsuccessful repeat applications - not unknown, some women resorted to desperate underhand tactics to become professed nuns, such as travelling abroad to take the veil in Orthodox convents in Poland or Moldavia, obtaining profession in men's monasteries, or lying about their martital status. ${ }^{37}$ At the same time, the consistory authorities' evident appreciation of 
Asklipiodata's qualities as a monastic candidate despite her unorthodox origins, is manifest in their eagerness to admit her to monastic profession even before the statutory term of her novitiate came to an end.

Settling in the female community of St Nicholas Holy Jordan most probably was not Asklipiodata's own choice, but a ruling on the part of the consistory authorities. The convent held the unenviable position at the bottom of the Kievan ecclesiastical structure, below the other two women's monasteries in the city. A monastery's place in the hierarchy was determined by the time of its foundation, but men's monasteries preceded convents on the pecking order, and, unlike their male counterparts, mothers superior had no ex officio position as members of the consistory. Older monastic communities tended to be more affluent and attracted more upper-class entrants. ${ }^{38}$ While in the later 1770s, thirteen (11\%) of the 121 sisters who inhabited the Sts Florus and Laurus community, Kiev's oldest, were noble, the St Nicholas Holy Jordan Monastery could only boast three (2.5\%) elite nuns. ${ }^{39}$ The available evidence amply demonstrates that eighteenth-century female monasticism in the Hetmanate territories was largely the preserve of commoners. ${ }^{40}$ It is not impossible that, while accepting of the future Asklipiodata's desire to take the veil, her status as an outsider dictated the metropolitan's decision to assign her to the St Nicholas Holy Jordan Monastery rather than to the older and more prestigious Sts Florus and Laurus or St John the Evangelist. Another female Jewish convert who wished to take monastic vows in a Kievan convent, known under her adopted Christian name, Anastasiia Ivanova, was recorded as a novice in the St Nicholas Holy Jordan in $1782 .^{41}$

The résumé of Asklipiodata's career on the 1771 list of the inmates of the 
St Nicholas Holy Jordan Monastery is a picture of a near-exemplary nun. Aged fifty-six, she was described as 'meek and persevering' (zhitiia krotkogo i terpelivogo), ablebodied, in good health and suited for the communal religious or general domestic tasks (poslushaniia). Asklipiodata was 'of little letters' (gramote malo izuchena), could sew and spin, and had had no penalties imposed on her for misdemeanors. ${ }^{42}$ Her semi-literate status was not unusual, although the language then spoken in Kiev, to which the documents of the time refer as 'the Little Russian dialect' (Malorossiiskoe narechie) was, of course, at best a second language to her. ${ }^{43}$ It is hard to tell to what extent this highly formulaic character description reflects the real Sister Asklipiodata, but it is clear enough that two years after her profession the then mother superior viewed her as a respectable member of the community, even if Asklipiodata had not been asked to carry out any specific communal tasks around the convent. In any event, under the non-communal regime such jobs were few and far between, and a foreigner with an unconventional religious background may not have been an ideal choice for a conciliar nun, a choirmistress, or a baker of the prosphora (small loaves of leavened bread used in Orthodox Eucharist). Administrative positions such as the superior's deputy (namestnitsa), bursar (kaznacheia) and store keeper (shafarka), went to the individuals chosen by the mother as best suited for the job and perhaps most affable to her. Their holders tended to become 'career nuns', often progressing from one role to another until they reached the top as mother superior. Such physical labour or crafts as the self-supporting nuns performed in their own households did not count as communal duties. 
In the early hours of the morning of 14 November 1776, the nuns of the St Nicholas Holy Jordan Monastery were woken up by the shouts and commotion that came from Asklipiodata's cell. Soon the astonished community witnessed Mother Alexandra's manservant Joseph Tertichnik struggling to restrain a loudly protesting Asklipiodata. When the nun's sympathisers approached the pair, one of the women was carrying a stick, which she used to hit Joseph, while the rest were pulling Asklipiodata away. Eventually freed from his grasp, a dishevelled and bloodied Asklipiodata was shouting rude insults directed at the mother superior. ${ }^{44}$ No inhabitant of nearly a hundred individual nuns' cells situated on convent grounds could have been left unaware of the disturbance. $^{45}$

Unsurprisingly, the two accounts that survive of the scandalous event, one supplied by Mother Alexandra, the other found in Sister Asklipiodata's formal complaint to the Metropolitan of Kiev Gavriil Kremenetskii, the highest ecclesiastical authority in the Hetmanate, provide very different versions of the incident. Addressing her plea to Father Cyril, the Archimandrite of the Kiev St Cyril Monastery and her immediate administrative superior, Alexandra begged to defend her honour, which, she claimed, had been injured by the public insults Asklipiodata hurled at her following the confrontation. Alexandra wrote that from the time she had assumed the office approximately a year earlier, Asklipiodata had been known to have frequently gone away from the convent without leave and come back repulsively drunk (bezobrazno p'ianaia). She also brought assorted secular persons back to her cell at any hour, where noisy drinking parties were held. As if this was not enough, she also struck an inappropriate relationship with the handyman Avram Nedelshchenko, a person of ill repute (khudogo obrashcheniia), whom 
the convent had engaged to perform major repairs on the old wooden church of St Nicholas. Mother Alexandra more than once summoned Asklipiodata to give account of her behaviour and asked to stop disturbing the peace of the community. All she claimed to have received from the sister by way of an explanation, was the defiant statement that without 'meat and men ... her dissolute nature could not do' (bezmiasa ibezmuzheskogo pola ... oboititsia posvoei strasti nemozhet). When Alexandra was informed that Nedelshchenko was spending the night of 14 November in Asklipiodata's cell, she sent her servant Joseph to break the company, reprimand the nun on the mother's behalf, and threaten her with imprisonment for the breach of discipline. In response, Asklipiodata attacked the manservant in her cell. Amidst the commotion, Nedelshchenko managed to escape, while several other nuns, among them a certain sister armed with a stick, who was herself under an ongoing consistory investigation, rushed to Asklipiodata's help. ${ }^{46}$

The formal complaint Sister Asklipiodata dictated to a scribe stated that she had been asleep when a wild banging on the door of her cell started. She had assumed the convent was on fire or under attack from brigands 'trying to break into her cell and steal her belongings'. Even by her own account, Asklipiodata's uppermost concern was thus about her own possessions rather than relics or other religious paraphernalia kept in the monastery church. When a candle was finally lit and the door unlocked, an 'insensibly drunk' Joseph, servant of Mother Alexandra, barged into the cell and, apparently without provocation, dealt Asklipiodata a heavy blow in the chest, knocking her down. When he proceeded to drag the half-naked sister from the house and march her in the direction of the superior's cell, the beating continued along the way. Fearing for her life, Asklipiodata 
shouted for help, but Mother Alexandra stifled her cries by holding the nun's mouth with her hand. The superior also hit her several times with the iron tip of her staff, which tore her flesh. Alexandra then ordered to take Asklipiodata to prison, but the sisters who heard her calls for help, rushed to her rescue.

Having lived to an old age, the nun wrote, she had never known such beatings and such shame, not even from her late husband (nemaloe uviech'e ibezchestie, kotorogo ia ichrez vsiu moiu zhizn' eshche nasebie ivzhizn' muzha moego nikogda nevidala). ${ }^{47}$ The phrasing of this statement is significant, as in it Asklipiodata evidently acknowledged her late husband's inherent right to administer humiliating bodily punishment he may have considered appropriate as her master, but denies the same right to her monastic superior. Asklipiodata left us no clear indication of what she thought about the vow of obedience to her superiors, the central rule of monastic life, but it seems obvious that she saw her body as inviolable to any unwarranted outside interference. It also seems meaningful that, prior to subjecting her to a degrading treatment in public, Joseph Tertichnik assaulted Asklipiodata within the confines of her own cell, whereby not only the rules of propriety, but her legal rights as its owner became violated.

The certificate of physical examination ( $k v i t)$, issued by Vasilii Blazhevskii, the Kiev beadle (voznyi), a middle-ranking officer responsible for maintaining law and order in the city, drawn on the following day, 15 November, recorded extensive bruising on Asklipiodata's chest and upper arms, as well as two wounds inflicted with a sharp instrument, presumably the iron tip of Alexandra's staff, the traditional and highly visible marker of her authority. ${ }^{48}$ The incident and its aftermath also highlight a surprising lack of regard for monastic and indeed womanly modesty on the part of all involved in the 
incident: not only was Asklipiodata reportedly dragged through the convent grounds dishevelled and half-naked by the servant Joseph, but this woman in her early sixties also willingly submitted herself to a close physical examination by the city official in order to obtain a formal record of her injuries. The latter yet again underscores the nun's strategic deployment of her body as property with defined rights and limitations attached to it. When this was likley to serve her interests, Asklipiodata did not hesitate to reveal her upper body, baring the chest, shoulders and upper arms in front of a male stranger for the purposes of a legal investigation.

Careful analysis of the two reports makes it clear that neither can be taken at face value, as the issues either woman chose to reveal in her submission are as important as those they were anxious to evade. Mother Alexandra's emphasis on Asklipiodata's drunkenness and offensive behaviour was meant to divert attention from the cruel and illicit physical punishment the nun received at her hands. In turn, Asklipiodata's legitimate complaints about the beating were also an attempt at silencing allegations of impropriety against her, which are not even mentioned in the petition she filed with the consistory. ${ }^{49}$ While the startling statement about the nun's alleged inability to stay away from 'meat and men' was almost certainly Mother Alexandra's own free interpretation of Asklipiodata's original wording lost to us, this fleshy reference could be a testimony to the simple truth that Sister Asklipiodata wished to reclaim the ownership of both her body and her soul from what she came to regard as an oppressive and sterile monastic regime. For all the numerious examples of monastic transgressions found in the archives of the Kiev Metropolitan Consistory, the case of Sister Asklipiodata appears unusual and extreme in her unabashed defiance of accepted norms. 
Among other things, the story might be a demonstration that for a nun being on good terms with her mother superior could make a difference between living in peace and knowing no peace. Unlike the universally respected Taisia Gorkovskaia, whose headship of the St Nicholas Holy Jordan Monastery (1762-75) gave rise to no recorded complaints from members of the community, already the first year of her successor Mother Alexandra's rule (1775-86) brought two separate conflicts. ${ }^{50}$ Alexandra proved to be either a more demanding or less tolerant monastic superior than her predecessor. While the list of monastic inmates Taisia compiled in 1771 does not contain a single negative characteristic of any of the sisters, all of whom were described as being 'meek and persevering' or 'honest and steady', a similar list composed in 1777 under Alexandra paints the picture of a community that had some distinctly rotten apples. It is true that she provided the majority of the sisters, including Sophia, with whom she had had an altercation the previous year, with positive characteristics (kachestv khoroshikh).$^{51} \mathrm{But}$ the monastic qualities of four nuns were described as 'undistinguished' (kachestv sredstvennykh or kachestv srednikh), whereas four others, including Asklipiodata, received bluntly unfavourable reports (kachestv nekhoroshikh).$^{52}$ Alexandra's forceful attitude is further illustrated by two formal complaints against her filed in September and October 1784 , in which a secular priest who served the monastic community claimed that she withheld the money that was due to him, and a sister complained of the beating she had received at the mother's hands..$^{53}$ As many as three complaints against Alexandra were submitted between 9 and 11 June 1786, the last year of her rule, one of them a collective denunciation by a group of sisters who accused her of purloining a large sum from the monastery treasury. ${ }^{54}$ As a rule, allegations of financial impropriety against 
mothers superior concealed internal struggles for power within a monastic community, with only a few of them proving to be genuine cases of the misappropriation of communal funds. These were often complicated because mothers, many of whom were women of private means, occasionally had to bail out convents in a state of financial distress, but expected various forms of gratitude in return. ${ }^{55}$ Under such circumstances distinguishing between the monastery treasury and the mother's private purse was no easy task.

Although Mother Alexandra's dislike of Asklipiodata is manifest, as is the style of management markedly different from that of her predecessor, it is doubtful that Asklipiodata's spectacular fall from grace was precipitated by the change at the top. It seems that Alexandra's arrival merely put her troubles in sharp relief. The year when she took over as the convent's head witnessed another significant event in Asklipiodata's monastic career: her first formal application for a period of leave away from the monastery. She wished to travel to the city of Elisavetgrad to collect eighty-five roubles she had lent her nephew, the local merchant Dmitrii Tishkov, and to visit other relatives who lived there. ${ }^{56}$ A substantial sum of money, enough to purchase at least two monastic cells, it shows that Asklipiodata was sufficiently well off to extend a long-term loan of this size.

The principle of enclosure for monastic women was outside Orthodox tradition, but the Petrine 1722 Addition to the Spiritual Regulation attempted to limit admission to convent grounds to priests and confessors, and to institute a blanket prohibition for ordinary nuns to leave their monasteries.$^{57}$ In the Ukrainian Hetmanate with its peculiar 
legal regime, however, exact boundaries within which imperial legislation applied remained a grey area. No gender-based distinction between the monks' and the nuns' freedom of movement can be observed, and, in spite of local ecclesiastical authorities' half-hearted attempts throughout the eighteenth century to regulate it, Ukrainian nuns were generally free to come and go during the day, although a prolonged stay away from the convent required a travel permit (pashport) issued by the metropolitan consistory. The attempt to enclose monastic women seems to have proved unworkable even in Great Russia, especially for the poor provincial monasteries, whose inmates had to go out to sell their crafts or beg for food; local bishops protested that the measure was unenforceable..$^{58}$

With Mother Alexandra's assent, Asklipiodata was granted two months' leave and issued with the necessary travel documentation in August $1775 .{ }^{59}$ Her destination, Elisavetgrad (now Kropyvnyts'kyi, Ukraine) had been founded in 1752 as the Fortress of St Elizabeth. It played a pivotal role in the internalisation of the borderland territory located at the intersection of the Russian-Polish border and the 'Wild Field', a wide strip of no-man's land at the southern frontier of the Russian Empire, which had been loosely controlled by the Cossacks of the Zaporozhian Host before its abolition in 1775 . Elisavetgrad achieved an official status as the provincial capital in $1775{ }^{60}$ Due to its favourable yet liminal situation at the intersection of trade routes, the city could have evolved into a place of de facto Jewish settlement from the time of its foundation. ${ }^{61}$ Asklipiodata's nephew, Dmitry Tishkov, who, judging by his first name of a distinctly Greek origin, was, like her, an earlier convert from Judaism, could have provided useful links between the local Christian merchant community and his enterprising former co- 
religionists, whose existence in the Empire continued to be precarious.

In the early summer of 1777 , less than two years after she had been granted permision to travel to Elisavetgrad, Asklipiodata again petitioned the consistory to be allowed to visit the city of Kaluga, a historic Russian town where her nephew had moved, under the pretext that she had to collect the money he owed her on a promissory note, and stating that she had a 'special need' (osoblivuiu nuzhdu) to stay away for three months. ${ }^{62}$ Advantageously situated at the intersection of several major roads and waterways, Kaluga was a hub on the trade routes to St Petersburg, Moscow, Ukraine, the Volga region, and as far afield as Britain, Holland, Turkey, Persia, and China. Transferring his business there was a sign of Dmitrii Tishkov's upward mobility and success as a merchant. Kaluga's proximity to Moscow, whose population, although not ethnically and religiously uniform, was certainly less heterogeneous than the motley populace of a frontier town like Elisavetgrad, possibly also implies a gradual fading away of his old Jewish identity.

The timing of Asklipiodata's two applications for travel permits in 1775 and 1777 may be significant. A sudden intensity of the nun's desire to reconnect with her family could be interpreted as a sign of disillusionment over her decision to enter an Orthodox monastery nearly a decade earlier. No evidence exists of her taking leave from the monastery to visit relatives in the first nine years since her entry there as a novice in 1766. Mother Alexandra stated in her report to the consistory about the night incident with Asklipiodata that the nun had already been known for her dissolute behaviour and drunkenness by the time Alexandra assumed her duties as the mother superior in 1775 . It is likely, therefore, that Asklipiodata's life had begun to unravel under Taisia 
Gorkovskaia's more benevolent (and perhaps also increasingly less effective) rule. ${ }^{63}$ Rather than being the cause of her downfall, Alexandra's firmer grip on the reins of power may have provoked a growing resentment and loss of control over the sister's already existing attachment to alcohol.

With regard to her alleged attraction to drink, it should be noted that monastic status in the Orthodox Church was never supposed to be synonymous with a teetotal existence. Like the rest of traditional European societies, in the East Slavic lands alcohol fulfilled a multiplicity of functions that included the dietary, the recreational, the therapeutic, and the economic, not to mention its role as a 'social lubricant' ${ }^{64}$ Apart from running distilleries on their estates, where alcohol was produced for sale and barter, all monasteries also purchased various types of intoxicating drink: imported wine for use in the church, mead for consumption on feast days, as well as vodka (usually called vino, 'wine', khlebnoe vino, 'grain wine', or gorelka, literally translated as 'combustible liquid', in early modern documents) and its humble relative, poorly distilled and evilsmelling hooch (sivukha) ${ }^{65}$ They could be used for internal consumption, gift giving or commerce ${ }^{66}$ Mothers superior were allocated a generous annual measure of several bucketfuls of the 'wine' produced on their convents' estates ${ }^{67}$ The rest of the sisters received smaller quantities of alcohol several times a year and used it for consumption or barter ${ }^{68}$ Throughout the eighteenth century Kievan metropolitans undertook measures to combat senseless drinking on the part of monastic personnel. ${ }^{69}$ Their approach to the problem, however, was moderate, as in Metropolitan Zaborovskii's warning to his fellow monastic not to frequent taverns, be seen drunk in public or miss church services: 'And if 
you should take a drink, do this for God's glory' ${ }^{70}$ In short, it can be safely assumed that alcohol and drinking per se were sufficiently part of the everyday reality not to elicit much comment. Contemporary archival records often mention drunkenness, but rarely as a stand-alone offence. For example, the priest Pavel Lobko claimed that he had locked up Sister Efrosiniia, a nun at the Florus and Laurus Monastery, whom he had discovered taking a short-cut through the cemetery of his church, because he had taken her for a drunken vagrant. ${ }^{71}$ The nun Makariia, accused of swearing at other sisters in a drunken state, denied the accusation as an attempt at character assassination, and claimed, in turn, that one of her detractors was a drunk.$^{72}$ Asklipiodata herself alleged that Mother Alexandra's attendant Joseph was 'insensibly drunk' when he beat her up. ${ }^{73}$

As a cultural reference meant to bolster the impression that the individuals against whom such accusations were made behaved in a generally disreputable manner, they should be approached with caution. To understand the context of reprehensible drinking behaviour is, therefore, more important than to establish that drink was actually taken. ${ }^{74}$ The offence caused by Asklipiodata's ostensible attachment to alcohol consisted in its public and demonstrative nature. This makes her stand out from other monastic individuals, references to whose drunken behaviour are found on the consistory files, none of whom was reported to consume alcohol in the company of other people or make a public display of themselves in a drunken state. Asklipiodata was said to have often wandered off from the convent without leave, come back late inebriated, and to have brought in unauthorised visitors, with whom she continued drinking in her cell. Interestingly, she also never explicitly denied these accusations. In short, if Asklipiodata was a drinker, she was a social drinker, somebody who sought solace in the company of 
strangers, rather than drowning her sorrows on her own or passing a glass or two on the quiet with some of her sisters in the convent. As well as a way to socialise, her drinking could be a form of escape from the frustrating emptiness of life in a convent.

To return to the fleshy allusions in the defiant statement Mother Alexandra quoted her as making about the impossibility of life 'without meat and men', while judging the strength of Asklipiodata's sexual appetite is impossible, it is not unreasonable to assume that at the age of sixty-one in 1776 , her need of human contact was greater than erotic urges. Following the passing away of her husband, Asklipiodata had been left with an emotional void, occasioned both by the loss of a life-time companion and by the absence of whatever communal and spiritual support they could have been enjoying as a couple. Under such circumstances religion could be expected to provide the necessary succour, and on entering convent Asklipiodata could be hoping to start sharing in the cycle of communal life. It would seem, however, that the status of an Orthodox nun she had ardently desired to achieve just a decade earlier and had obtained sooner than could be anticipated, failed to deliver on its promise, because she had set her expectations too high. Monasticism was traditionally hailed as the pinnacle of Orthodox religious life, but, echoing Hertz in her study of female Jewish conversions in Berlin at the dawn of modernity, one might wonder 'whether anyone who has shut the door on so much of her past and her heritage can ever really be happy in a radically new identity. To change one's social position and belief structure simultaneously and fundamentally seems to have made life emotionally confusing and painful for the women involved' ${ }^{75}$ The ups and downs of Asklipiodata's monastic career highlight her search for an engagement with 
religion that had to be grounded in emotion to carry a meaning.

A foreigner and outsider who, on taking the veil, found herself nominally living in a community, but was in fact trapped in one of a hundred-plus monastic cells, whose predominantly lower-middle class inhabitants mostly minded their own business, ate their own meals and only occasionally met in church for the liturgy, Asklipiodata felt no less lonely in her monastic life than she had been as a widow left in an empty house. Staying away from 'meat and men', that is, observing Orthodox fasts that lasted for up to six weeks at at time, and only keeping the company of women, offered an uncertain path to eternal salvation. Asklipiodata's problem appears to have been in a clash between the idealised representation proliferated by the society around her, and the actual lived experience of an unreformed and shapeless monastic existence in an eigtheenth-century Orthodox convent, a conflict between the intangible essence of faith and the often contradictory substance of religious life.

The last we hear about her is December 1777. Just over a year after the nighttime disturbance in the St Nicholas Holy Jordan Monastery, which left her physically and emotionally scarred, Asklipiodata quit the convent, sold her cell to a secular woman who wished to settle there, and was moving between the houses of various secular acquaintances in the nearby Podil district, who offered her shelter. ${ }^{76}$ Asklipiodata's name is absent from the list of the St Nicholas Holy Jordan's inmates, composed in $1780 .{ }^{77}$ Since monastic status in the Orthodox Church is indelible and cannot be renounced or taken away, her position was untenable in the long run, and ecclesiastical authorities would have to interfere. A forcible transfer to a provincial convent was a likely outcome of her spectacular downfall. It is also possible, however, that ready cash in hand: the 
money Asklipiodata obtained for her cell and any other liquid assets that remained within her reach, could have provided the means to escape detention and punishment. Private property and personal wealth thus served not only as a gateway to monastic profession and acquisition of specific social privileges, it also gave sisters independent means to maintain themselves within convent walls and relative freedom of movement, as well as becoming a potential lifebuoy for the disobedient and the disillusioned.

Sister Asklipiodata's Jewish and foreign origins afford an insight through the eyes of a convert from another religion into the state of Orthodox monasticism before the secularisations of the eighteenth century. Initially pulled in by the promise of 'angelic life', she underestimated its daily struggles and became fristrated when her expectations appeared not to have been met. Above all, Asklipiodata's life story is a poignant illustration that property relationships, which permeated Orthodox monastic life under the old ideorrhythmic regime affected not just individual members of convent communities. On the level of quotidian concerns they shaped monastic life by creating a dense web of interactions between the monastery and the secular world. On the higher level of ecclesiastical structures, attachment to personal property often stood in the way of maintaining basic monastic principles, upset relationships within communities, impacted on the way individual nuns thought about themselves and regarded their ecclesiastical superiors, and opened up opportunities for manipulation on all sides. The official Orthodox Church was reluctant to press the rule of poverty on its monastic personnel. Monasticism had always been, and still remained, a mainstay of its claim of spiritual authority and moral superiority. An attempt at internal reform would have been tantamount to an implicit criticism of the status quo and grist to the mill of the 
proponents of further secularisation. For an individual under such conditions realising the higher calling of monastic life in full must have been no easier than for a camel to pass through the eye of a needle.

${ }^{1}$ For earlier periods some excellent work has been produced by the historians of Byzantium: Évelyne Patlagean, 'L’histoire de la femme déguisée en moine et l'evolution de la santeté feminine à Byzance', Studi Medievali Ser. 3 xvii (1976), 597-623; AliceMary Talbot, 'A comparison of the monastic experience of Byzantine men and women', Greek Orthodox Theological Review xxx (1985), 1-20; Donald M. Nicol, The Byzantine lady: ten portraits, $1250-1500$, Cambridge 1994, 33-47, 59-70. More recently the historians of early modern Christianity in the Middle East have offered a number of contributions that discuss post-Tridentine Melkite and Maronite female monasticism, principally in Lebanon and Syria: Avril M. Makhlouf, 'Hindiyyah 'Ujaymî and the monastic life: the rule of life for the Congregation of the Sacred Heart', Parole d'Orient xviii (1993), 293-302; Bernard Heyberger, Hindiyya, mystique et criminelle (17201798), Paris, 2001, more recently translated into English as Hindiyya: mystic and criminal, 1720-1798: a political and social crisis in Lebanon, trans. Renée Champion, Cambridge 2013; Sabine Mohasseb Saliba, Les monastères maronites doubles du Liban: entre Rome et l'Empire ottoman (XVIIe-XIXe siècles), Paris 2008. A handful of works published over the last thirty years or so explore convents in early modern Muscovite and Imperial Russia: Marie A. Thomas, 'Muscovite convents in the seventeenth century', Russian History x (1983), 230-42; Brenda Meehan, 'Popular piety, local initiative, and 
the founding of women's religious communities in Russia, 1764-1907', in Stephen K. Batalden (ed.), Seeking God: the recovery of religious identity in Orthodox Russia, Ukraine, and Georgia, DeKalb 1993, 83-105; E. B. Emchenko, 'Zhenskie monastyri v Rossii' [Women's monasteries in Russia], in N. V. Sinitsyna (ed.), Monashestvo $i$ monastyri v Rossii, XI-XX veka: istoricheskie ocherki [Monasticism and monasteries in Russia from the eleventh to the twentieth centuries: historical sketches], Moscow 2002, 245-84; William Wagner, 'Female Orthodox monasticism in eighteenth-century Imperial Russia: the experience of Nizhnii Novgorod', in Rosslyn Marsh and Alessandra Tosi (eds), Women in eighteenth-century Russian culture and society, 1700-1825, Basingstoke 2007, 191-218; Marlyn L. Miller, 'Under the protection of the Virgin: the feminization of monasticism in Imperial Russia, 1700-1923', unpubl. PhD diss., Brandeis University 2009; Angelika Schmähling, Hort der Frömmigkeit - Ort der Verwahrung: Russische Frauenklöster in 16.-18. Jahrhundert, Stuttgart 2009. Sophia Senyk's seminal monograph Women's monasteries in Ukraine and Belorussia to the period of suppression (Orientalia Christiana Analecta ccxxii, 1983) still remains the only work of this scale in English offering a summary of female monasticism in pre-modern Belarus and Ukraine. A small body of research, mostly in non-Western European languages, has been produced in the last decade by the historians of early modern Ukraine: Oleh Dukh, 'Przywileje królewskie dla prawosławnych i unickich monasterów żeńskich w eparchiach lwowskiej i przemyskiej w XVII i XVIII wieku' [Royal privileges for Orthodox and Uniate female monasteries in the Lviv and Przemyśl dioceses in the seventeenth and eighteenth centuries], in M. Derwich, A. Pobóg-Lenartowicz (eds.), Klasztor w państwie średniowiecznym i nowożytnym [Monastery in the medieval and modern society], 
Wrocław 2005, 149-61; Svetlana V. Sokhan', 'Kyivs'ki Bohoslovs'kyi ta Iordans'kyi zhinochi monastyri XVI-XVIII st.: spletinnia doli v istorychnomu prostori’ [The Kiev St John the Baptist and Holy Jordan Monasteries from the sixteenth to the eighteenth centuries: an intertwining of historical destinies], Rukopysna ta knyzhkova spadshchyna Ukrainy [Manuscript and book heritage of Ukraine] 13 (2009), 79-98; Olha Krainia, Kyievo-Pechers'kyi zhinochyi monastyr XVI-pochatku XVIII st. i dolia ioho pam'iatok [The Kiev Pechersk female monastery in the sixteenth and early eighteenth centuries, and the fate of its material heritage], Kiev 2012; Liudmila V. Charipova, 'Spare ribs? Early modern female monasticism in the East Slavic lands', History Compass xii (2014), 5161, pp. 51-2.

${ }^{2}$ Zenon Kohut, 'The problem of Ukrainian Orthodox Church autonomy in the Hetmanate (1654-1780s)', Harvard Ukrainian Studies xiv (1990), 364-76, pp. 366-7.

${ }^{3}$ Liudmila V. Charipova, 'Virgins and widows: imperial legislation and practices of admission to the novitiate and profession in Ukrainian women's monasteries (17221786)', Slavonic and East European Review xc (2012), 262-87, pp. 286-7.

${ }^{4}$ Sophia Senyk, 'Introduction', Manjava Skete: Ukrainian monastic writings of the seventeenth century, trans. eadem (Cistercian Studies Series clcii, 2001) 9-65, p. 41. ${ }^{5}$ Central State Historical Archive of Ukraine, Kiev (hereafter CSHAUK), fonds 915, op. 1 , no. 6 , fo. 11 ; fonds 127 , op. 136 , no. 35 , fo. 1 . The nineteenth-century Russian historian Nikolai Suvorov cites numerous examples from seventeenth- and eighteenthcentury Muscovite convents, when secular men who bought or inherited nuns' cells lived there permanently, going out to work and returning 'home' on a daily basis: Nikolai Suvorov, 'Zametki o muzhesko-zhenskikh monastyriakh v drevnei Rossii' [Notes on the 
mixed monasteries for men and women in ancient Russia], Arkhiv istoricheskikh $i$ prakticheskikh svedenii, otnosiashchikhsia do Rossii [The archive of historical and practical knowledge related to Russia] iv (1860-61), 38-46.

${ }^{6}$ Laura S. Underkuffler, The idea of property: its meaning and power, Oxford 2003, 16.

${ }^{7}$ Senyk, 'Introduction', 40.

${ }^{8}$ See Hyppolète Delehaye, 'Byzantine monasticism', in Norman H. Baynes and H. St. L. B. Moss (eds), Byzantium: an introduction to East Roman civilization, Oxford 1948, 136-65, p. 157.

${ }^{9}$ V. Klymov, 'Petro Mohyla i ukrains'ke chernetstvo' [Peter Mohyla and the Ukrainian monasticism], in A. Kolodnyi and V. Klymov (eds), Fenomen Petra Mohyly: biohrafiia, diial'nist', pozytsiia [The phenomenon of Peter Mohyla: biography, actions, world view], Kiev 1996, 181-211,p. 190.

${ }^{10}$ The Pale of Settlement, instituted in 1791, demarcated the western areas of the Russian Empire, where free Jewish residency was permitted.

${ }^{11}$ The size and vibrancy of the Jewish population the Partitions brought to the Russian Empire resulted in the shift of the historiographical focus toward the post-Partitions period and the inequities of the Pale of Settlement. Against a sizeable body of research in Jewish assimilation in the Russian Empire including Ukraine after 1791, the historiography of pre-modern Jewish settlement in the Ukrainian lands is comparatively small, see: B. R. Ts., 'Materialy dlia istorii vodvoreniia ievreev na zhitel'stvo v gorode Kieve' [Materials for the history of Jewish settlement in the city of Kiev], Den': organ russkikh ievreev [Day: a Jewish organ in Russia] xxi (1870), 345-7; xxii (1870), 360-2; M. Sh-r, 'Pravo zhitel'stva evreev v Kieve (istoriko-iuridicheskii etiud)' [The right of 
Jewish residency in Kiev (a historico-juridical sketch)], Razsvet: organ russkikh evreev [Dawn: a Jewish organ in Russia] xxvii (1881), 1044-8; M. Kulisher, 'Pol'sha s evreiami i Rus' bez evreev na rubezhe XVII i XVIII veka' [Poland with Jews and Russia without Jews at the turn of the seventeenth and eighteenth centuries], Evreiskaia starina: trekhmesiachnik Evreiskogo istoriko-etnograficheskogo obshchestva [Jewish antiquities: a quarterly of the Jewish Historico-Ethnographical Society] iii (1910), 214-34;

S. M. Dubnow, History of the Jews in Russia and Poland from the earliest times until the present day, trans. by I. Friedlaender, i, Philadelphia 1916; A. Kaustov, 'Ievrei pid vladoiu Lytvy ta Pol'schchi (XIV-XVIII st.)' [Jews under Lithuanian and Polish rule (the fourteenth to the eighteenth centuries)], in Leonid Finberg and Volodymyr Liubchenko (eds), Narysy z istorii ta kul'tury ievreiv Ukrainy [Sketches in the history and culture of Jews in Ukraine], 2nd ed., Kiev 2008, 38-59; Nathan M. Meir, Kiev, Jewish metropolis: a history, 1859-1914, Bloomington 2010, 23.

${ }^{12}$ A clear reference to her foreign origins: 'the nun Sklipiodota [sic], a native of the [Holy Roman] Empire' (Sklipiodota tsesarka) is found in official records: Central State Historical Archive of Ukraine, Kiev (subsequently CSHAUK), fonds 127, op. 171, no. 100 , fo. 3 ; fonds 915 , op. 1 , no. $12 \mathrm{a}$, fos $2 \mathrm{r}-\mathrm{v}$. Asklipiodata's age (she was fifty-one in 1766) and place of birth are each mentioned on two occasions: '[she] comes from the city of Prague [in] the [Holy Roman] Empire' (roda tsesarskogo iz goroda Pragi):

CSHAUK, fonds 915, op. 1, no. 8, fo. 9v; ibid. op. 1, no. 11, fo. 25. On Prague as a Jewish city see L. Kochan, The making of Western Jewry, 1600-1819, Basingstoke 2004, $116,170$.

${ }^{13}$ CSHAUK, fonds 915 , op. 1 , no. 8 , fo. 9 v. 
${ }^{14}$ Kochan, The making of Western Jewry, 169-71, 174. Also see Hillel J. Kieval, Languages of community: the Jewish experience in the Czech lands, Berkeley 2000, 23.

${ }^{15}$ Paula E. Hyman, Gender and assimilation in modern Jewish history: the roles and representation of women, Seattle 1997, 20-1. On Russian imperial government's commitment to religious marriage see Paul W. Werth, 'Empire, religious freedom, and the legal regulation of "mixed" marriages in Russia", Journal of Modern History 80 (2008), 296-331, pp. 299-300.

${ }^{16}$ Polnoe sobranie zakonov Rossiiskoi imperii, Sobranie pervoe [A full collection of the laws of the Russian Empire, First series] xi, St Petersburg 1830, 727-8; cf. CSHAUK, fonds 127 , op. 166 , no. 95 , fo. 1 .

${ }^{17}$ For the statistics on Jewish population of the Polish-Lithuanian Commonwealth in the second part of the eighteenth century see Gershon David Hundert, Jews in PolandLithuania in the eighteenth century: a genealogy of modernity, Berkeley 2004, 22.

${ }^{18}$ Hundert estimates that by the $1760 \mathrm{~s}, 44 \%$ of the Commonwealth's Jewry inhabited its eastern provinces, see his, Jews in Poland-Lithuania, 25. Cf. Kaustov, 'Ievrei pid vladoiu Lytvy ta Pol'schchi', 55.

${ }^{19}$ Jeremy Cohen, 'The mentality of the medieval Jewish apostate: Peter Alfonsi, Hermann of Cologne, and Pablo Christiani', in Todd M. Endelman (ed.), Jewish apostasy in the modern world, New York 1987, 20-47, pp. 20-1.

${ }^{20}$ Kochan observes that the majority of Jews baptised in Bohemia by 1720 belonged to the lower and lower-middle classes: The making of Western Jewry, 120. Likewise, Deborah Hertz argues that before 1770 most converts in Prussia tended to be poor, see her 'Emancipation through intermarriage? Wealthy Jewish salon women in old Berlin', in 
Judith R. Baskin (ed.), Jewish women in historical perspective, 2nd ed., Detroit 1998, 193-207, p. 201.

${ }^{21}$ CSHAUK, fonds 127, op. 158, no. 53, fos 1r-5r; ibid. op. 166, no. 95, fos 1r-8r; ibid. op. 167, no. 95, fos 2r-22v.; ibid. op. 170, no. 7, fos 3r-12v. Cf. Deborah Hertz, 'Seductive conversions in Berlin, 1770-1809', in Endelman (ed.), Jewish apostasy, 4882 , pp. 52, 58-9.

${ }^{22}$ When both parents of the Jewish girl Anna had died in the Right-Bank Ukrainian city of Volodymyr Volyns'kyi, she at first converted to Roman Catholicism, but, on being adopted by an Orthodox family, accompanied them to Kiev in 1763, where she asked to be allowed to assume Orthodox baptism. Her case also demonstrates that, from the Russian authorities' perspective, an earlier conversion to another Christian faith was void, as they treated Anna as a Jewish, rather than Catholic, convert: CSHAUK, fonds 127 , op. 158 , no. 53 , fos $1 \mathrm{r}-5 \mathrm{r}$.

${ }^{23}$ CSHAUK, fonds 915 , op. 1 , no. 8 , fo. 9v. Asklipiodata's monastic name is extremely rare, as only one other Sister Asklipiodata appears on the eighteenth-century lists of monastic personnel in Kiev, see CSHAUK, fonds 127, op. 153, no. 85, fo. 21.

${ }^{24}$ CSHAUK, fonds 915, op. 1, no. 8, fo. 9v. Cf. Charipova, 'Virgins and widows', 274. ${ }^{25}$ For a comparison between Jewish and Christian views on afterlife and salvation respectively see Leon Klenyts'kyi [Leon Klenicki] and Dzhefri Vaigoder [Geoffrey Wigoder] (eds), Iudeo-khrystyians'kyi dialoh: slovnyk-dovidnyk [The Jewish-Christian dialogue: a dictionary and reference guide], Kiev 2015, 84-90, 204-12.

${ }^{26}$ Cohen, 'The medieval apostate', 35 . 
${ }^{27}$ Chava Weissler, 'The traditional piety of Ashkenazic women', in Arthur Green (ed.), Jewish spirituality from the sixteenth-century revival to the present, London 1987, 24575, pp. 247-52; eadem, 'Prayers in Yiddish and the religious world of Ashkenazic women', in Baskin (ed.), Jewish women in historical perspective, 159-81, pp. 171-4. For later examples of tkhines see ChaeRan Y. Freeze and Jay M. Harris (eds), Everyday Jewish life in Imperial Russia. Select documents (1772-1914), Waltham 2013, 163-4. ${ }^{28}$ See Ada Rapoport-Albert, Women and the messianic heresy of Sabbatai Zevi, 16661816, trans. Deborah Greniman, Oxford 2011, 35-6, 60-1, 81.

${ }^{29}$ Cited in Nathaniel Deutsch, The Maiden of Ludmir: a Jewish holy woman and her world, Berkeley 2003, 98; on women's cemetery visits see ibid. 99. Rumour even had it that the Maiden had visited and been offered sanctuary in the Greek Catholic convent of St Elias in Volodymyr Volyn'skyi (Ludmir): ibid. 161-5.

${ }^{30}$ Hundert, Jews in Poland-Lithuania, 240.

${ }^{31}$ The 1771 list of monastic personnel specifies the period of two years between her entry to the convent as a secular person and the time when she took the veil, see CSHAUK, fonds 915 , op. 1 , no. 8 , fo. 9 v.

${ }^{32}$ See Charipova, 'Virgins and widows', 278-9.

${ }^{33}$ Charipova, 'Virgins and widows', 275.

${ }^{34}$ Charipova, 'Virgins and widows', 280-1.

${ }^{35}$ Only 1761 , when after a hiatus of nearly forty years imperial authorities expressly encouraged the profession of suitable candidates in monasteries, and twenty-two sisters took the veil in the St Nicholas Holy Jordan Monastery, rivals 1769 for the number of women admitted to profession within a year, see Charipova, 'Virgins and widows', 280. 
${ }^{36}$ CSHAUK, fonds 127, op. 156, no. 4; ibid. no. 76 ; op. 157, no. 39; ibid. no. 43.

${ }^{37}$ Charipova, 'Virgins and widows', 270-1.

${ }^{38}$ Iryna Margolina and Vasylii Ulianovs'kyi, Kyivs'ka obytel' Sv Kyryla [The Kiev Monastery of St Cyril], Kiev 2005, 147. Cf. Anthony Bryer, 'The late Byzantine monastery in town and countryside', Studies in Church History xvi (1979), 219-41, pp. 228-9, and Elizabeth A. Lehfeldt, 'Discipline, vocation and patronage: Spanish religious women in a Tridentine microclimate', Sixteenth Century Journal xxx (1999), 1009-30, p. 1027.

${ }^{39}$ CSHAUK, f. 915, op. 1, no. 8; G. L[azarevskii], ‘K istorii kievskikh zhenskikh monastyrei' [Concerning the history of female monasteries in Kiev], Kievskaia starina [The Kiev antiquities], liii (1896), 8-13, pp. 9-10. Although it had originally been founded in the early seventeenth century and occupied the second place after the Sts Florus and Laurus Monastery, the community of St John the Evangelist had no noble members, which is attributable to its small size: only fifty-two sisters at the time:

L[azarevskii], 'K istorii kievskikh zhenskikh monastyrei', 11 .

${ }^{40}$ Charipova, 'Virgins and widows', 272.

${ }^{41}$ CSHAUK, fonds 127 , op. 176 , no. 64 , fo. 2 v.

${ }^{42}$ CSHAUK, fonds 915 , op. 1 , no. 8, fo. 10.

${ }^{43}$ Charipova, 'Virgins and widows', 281-2.

${ }^{44}$ CSHAUK, fonds 127 , op. 171 , no. 100 , fos $1 \mathrm{r}-\mathrm{v}$, $3 \mathrm{v}$; fonds 915 , op. 1 , no. 12a, fos $2 \mathrm{r}-$ v.

${ }^{45}$ A document composed just over a decade later, in 1787, makes reference to 108 cells, see Sokhan', 'Kyivs'ki Bohoslovs'kyi ta Iordans'kyi zhinochi monastyri’, 93. 
${ }^{46}$ The sister with a stick could have been Ievanfa, who, along with Asklipiodata, would be described as a nun whose alleged misdemeanors were investigated by the consistory authorities in 1777: CSHAUK, fonds 915 , op. 1 , no. 11 , fo. $24 \mathrm{v}$.

${ }^{47}$ CSHAUK, fonds 127 , op. 171, no. 100 , fos $1 \mathrm{r}-\mathrm{v}$.

${ }^{48}$ CSHAUK, fonds 127 , op. 171 , no. 100 , fo. 2.

${ }^{49} \mathrm{Cf}$. the case of another Kievan nun accused of staging a drunken night-time brawl in her convent, who countered these allegations with strenuous protests and assurances of her innocence: CSHAUK, fonds 127, op. 151, no. 13, fos 1, 4.

${ }^{50}$ In addition to Alexandra's conflict with Asklipiodata described here, a record of an earlier, seemingly unrelated, dispute with Sister Sophia is found on the consistory files: CSHAUK, fonds 127, op. 171, no. 6.

${ }^{51}$ CSHAUK, fonds 915 , op. 1 , no. 11 , fos $19 v-20$ r.

52 'Undistinguished': CSHAUK, fonds 915, op. 1, no. 11, fos 6, 8, 13v, 22; sisters described unfavourably: ibid., fos $6 \mathrm{v}, 22 \mathrm{v}, 24 \mathrm{v}, 25$.

${ }^{53}$ CSHAUK, fonds 127, op. 178, nos 104, 122.

${ }^{54}$ Collective letter about the misappropriation of the convent funds by Alexandra: CSHAUK, fonds 127, op. 180, no. 36, fos 2r-2v; individual complaints: ibid., nos 37, 46. ${ }^{55}$ Mother Agafia Humenitskaia, a noblewoman who led the community of the Kiev Sts Florus and Laurus Monastery in the first half of the seventeenth century, funded the restoration of its church, the building of monastic cells and boundary fence, and purchased several plots of land in the city to improve the convent's financial standing: CSHAUK, fonds 167 , op. 2 , no. 2 , fos $45,46 \mathrm{v}$. The scale of the mothers' charity visibly shrunk in the eighteenth century, but they still occasionally felt compelled to dip into 
their private purses to keep the community afloat: Institute of the Manuscript, Vernadskyi National Library of Ukraine (hereafter IM VNLU), fonds 232, no. 255, fo. 4; CSHAUK, fonds 127 , op. 167 , no. 140 , fo. 38 .

${ }^{56}$ CSHAUK, fonds 127 , op. 170 , no. 61 , fo. 4.

${ }^{57}$ Polnoe sobranie postanovlenii i rasporiazhenii po vedomstvu pravoslavnogo ispovedaniia Rossiiskoi imperii [The complete collection of laws and regulations concerning the Orthodox Church administration in the Russian Empire] ii, St Petersburg $1872,252$.

${ }^{58}$ Emchenko, 'Zhenskie monastyri v Rossii', 260.

${ }^{59}$ CSHAUK, fonds 127 , op. 170 , no. 61 , fo. 6 .

${ }^{60}$ A. Murashkintsev, 'Elizavetgrad', in Entsiklopedicheskii slovar' Brokgauza i Efrona [The encyclopaedic dictionary of Brockhaus and Efron] xi-a, St Petersburg, 1894, 61416, p. 614; O. G. Bazhan, 'Kirovohrad', in Entsyklopediia istorii Ukrainy [The encyclopaedia of the history of Ukraine] iv, Kiev 2007, 329-30, p. 329.

${ }^{61}$ Serhii Didyk, 'Etnichnyi sklad naselennia Novoslobids'koho kazats'koho polku' [The ethnic composition of the Novaia Sloboda Cossack regiment], Zbirnyk tez naukovoi konferentsii studentiv, aspirantiv ta molodykh vchenykh 2007 r. [Collection of abstracts of the papers presented at the academic conference of undergraduate and postgraduate students, and early-career researchers, 2007], Zaporizhzhia 2007, 51-4, p. 54.

${ }^{62}$ CSHAUK, fonds 127, op. 170, no. 61, fo. 8. A Dmitrii Avtonomovich Tishkov (172777) was registered as a merchant in Kaluga: N.I. Kozhevnikova (comp.), 'Kaluzhskie kuptsy' [Database of the merchants of Kaluga], at <http://kk.convdocs.org/docs/index101012.html?page=2>, accessed 5 Feb. 2016. 
${ }^{63}$ Father Amphilochius, the Archimandrite of the St Cyril Monastery and Taisia Gorkovskaia's immediate ecclesiastical superior, rebuked her for the laxness of her rule in a letter of 17 August 1770: CSHAUK, fonds 915, op. 1, no. 6, fos 7r-8r.

${ }^{64}$ A. Lynn Martin, Alcohol, sex, and gender in late medieval and early modern Europe, Gordonsville 2001, 7.

${ }^{65}$ See CSHAUK, fonds 127 , op. 1027 , no. 8, fo. 3; ibid., op. 151, no. 85, fos 3v., 27v.; ibid., op. 1021, no 28, fos 2r-4v.

${ }^{66}$ CSHAUK, fonds 127 , op. 151 , no. 85 , fo. $17 \mathrm{v}$.

${ }^{67}$ CSHAUK, fonds 127 , op. 151 , no. 85 , fo. $17 \mathrm{v}$.

${ }^{68}$ CSHAUK, fonds 127 , op. 151 , no. 85 , fo. 19.

${ }^{69}$ Maksym Iaremenko, Kyivs'ke chernetstvo XVIII st. [The Kiev monasticism in the eighteenth century], Kiev 2007, 170.

${ }^{70}$ D. V[ishnevskii], 'Kievskii mitropolit Rafail Zaborovskii i ego mery k ispravleniiu dukhovenstva' [The Kiev Metropolitan Rafail Zaborovskyi and his efforts to improve the clergy], Kievskaia starina [The Kiev antiquities] iii (1899), 397-423, pp. 416-7.

${ }^{71}$ IM VNLU, fonds 232 , no. 286 , fo. 26v.

${ }^{72}$ CSHAUK, fonds 127 , op. 151 , no. 13 , fos 1,4 .

${ }^{73}$ CSHAUK, fonds 127 , op. 171 , no. 100 , fo. 1.

${ }^{74}$ Cf. Martin, Alcohol, sex, and gender, 12.

${ }^{75}$ Hertz, 'Emancipation through intermarriage?', 204. Cf. ChaeRan Y. Freeze, 'The Mariinsko Sergievskii shelter for converted Jewish children in St Petersburg', in Eugene M. Avrutin and Harriet Murav (eds), Jews in the East European borderlands: essays in honor of John D. Klier, Boston 2012, 27. 
${ }^{76}$ CSHAUK, fonds 915, op. 1 , no. $12 \mathrm{a}$, fo. 5 .

${ }^{77}$ CSHAUK, fonds 915, op. 1, no. 13. 